\title{
Margaret McCartney: Second use patents-why do we have to prescribe branded Lyrica for pain?
}

\author{
Margaret McCartney general practitioner, Glasgow
}

You say Lyrica; I say pregabalin. Branded Lyrica is licensed for pain, anxiety, and epilepsy; generic pregabalin is cheaper. But Pfizer has a second use patent on Lyrica for pain (granted 2003-17), which trumps generic use in this condition. So pregabalin can be prescribed generically for epilepsy and anxiety, but for pain, the only licence is prescription as Lyrica.

Pfizer wrote to pharmacists this year to tell them that generic prescribing of pregabalin for pain would be "unlawful" and would be contrary to government policy "of rewarding additional research by the granting of a second use patent." NHS England then told all GPs to prescribe the branded drug for pain. ${ }^{2}$ Pfizer said that it does "not wish" to take legal action ${ }^{3}$ - but prescribing data may identify individual doctors. Should pharmacists check the drug's use with every patient-for example, when a family member collects a repeat script, threatening the patient's confidentiality?

This is a mess. Guidance from the General Medical Council until 2013 stated that, given the evidence of benefit and safety, doctors could use unlicensed drugs when "satisfied that an alternative, licensed medicine would not serve the patient's needs." Similarly, off-label prescribing was justified when doctors were "satisfied that it would better serve the patient's needs than an appropriately licensed alternative."

The GMC consulted on this in 2012, and one redraft suggested that "unlicensed or off-label medicines could be prescribed where ... a doctor judged that the medicine was as safe and as effective as an appropriately licensed alternative."

This would have cleared the way for using cheaper unlicensed or off-label generics; however, the Association of the British Pharmaceutical Industry opposed it. Given the European Union directive on human medicinal products, the GMC concluded that unlicensed drugs could be prescribed only if there were a "special need" that "could not be taken to encompass" situations where there was "a licensed alternative."

This is yet to be tested in court or by the GMC in a fitness to practise proceeding. And correspondence in The BMJ over a similar situation with the cheaper, unlicensed Avastin versus the more expensive, licensed Lucentis for macular degeneration has shown great debate as to when an unlicensed drug can be legally used.
The ramifications are yet to be fully felt. The GMC recently stated, "The European Court has in effect ruled out the adoption of blanket policies that permit the 'off-label'/unlicensed prescribing of medicines on the grounds of cost." " Current GMC guidance says that you can use unlicensed drugs only if "for medical reasons, it is necessary to do so to meet the specific needs of the patient." ${ }^{, 8}$ Economy doesn't cut it.

Taken to ridiculous conclusion, this could mean breaching GMC guidance when prescribing amitriptyline for pain (unlicensed for this indication) when other drugs for neuropathic pain are available—or selenium sulphide shampoo, unlicensed for pityriasis versicolor.

Here comes the second medical use patent industry. Will the authorities stand up for cost effective prescribing, or is this the beginning of a whole new franchise of drug waste?

Competing interests: I have read and understood the BMJ policy on declaration of interests and declare the following interests: I'm an NHS GP partner, with income partly dependent on Quality and Outcomes Framework points. I'm a part time undergraduate tutor at the University of Glasgow. I've written two books and earn from broadcast and written freelance journalism. I'm an unpaid patron of Healthwatch. I make a monthly donation to Keep Our NHS Public. I'm a member of Medact. I'm occasionally paid for time, travel, and accommodation to give talks or have locum fees paid to allow me to give talks but never for any drug or public relations company. I was elected to the national council of the Royal College of General Practitioners in 2013 and am chair of its standing group on overdiagnosis. I have invested a small amount of money in a social enterprise, Who Made Your Pants?

Provenance and peer review: Commissioned; not externally peer reviewed.

Follow Margaret on Twitter, @mgtmccartney

Letter from legal director of Pfizer to UK pharmacists. 15 January 2015; available at http: //margaretmccartney.com/2015/03/17/lyrica-vs-pregabalin/.

2 NHS England. Schedule 1: the pregabalin guidance; letter to GPs. 6 March 2015. www. england.nhs.uk/wp-content/uploads/2015/03/pregabalin-guidance.pdf.

3 Statement from Pfizer on Lyrica. 10 March 2015; available at http://margaretmccartney. com/2015/03/17/lyrica-vs-pregabalin/.

4 General Medical Council. Good practice in prescribing medicines 2008-2013. http://bit.ly/ 1LkuwLw.

5 General Medical Council. Guidance on prescribing: board meeting minutes. 17 April 2012. www.gmc-uk.org/6b_Guidance_on_Prescribing.pdf_48443029.pdf. 
$6 \quad$ Cohen D. Why have UK doctors been deterred from prescribing Avastin? BMJ 2015;350:h1654.

General Medical Council. GMC responds to calls to remove barriers preventing 'off licence' use of Avastin; response to letter from NHS Clinical Commissioners. 5 March 2015. www. gmc-uk.org/news/26328.asp.
8 General Medical Council. Prescribing guidance: prescribing unlicensed medicines. 2013. www.gmc-uk.org/guidance/ethical_guidance/14327.asp.

Cite this as: BMJ 2015;350:h2734

(c) BMJ Publishing Group Ltd 2015 